SECTION 21. Pedagogy. Psychology. Innovations in the field of education.

Svetlana Valerievna Malazoniia Ph.D., associate professor of the Department of Labour Protection and Engineering Pedagogy of the Educational scientific professionally Pedagogical Institute of the Ukrainian Engineering

- Pedagogical Academy myemai1888@yandex.ua

\title{
THE PERSONAL DEVELOPMENT OF A PROFESSIONAL OF ENGINEER- PEDAGOGUE
}

Abstract: The development of the person determines a choice of a trade and preparation for it. Choice and development of professional activity determine strategy of person's development. The professional development at different stages of ability to live of the man is the result, or means of person's development.

The earlier directed person's development and professional development will begin, in the greater degree it is possible to predict psychological well-being, satisfaction by life and person's growth of each man in modern, varying world.

Key words: identity development, self-awareness, growth.

\section{РАЗВИТИЕ ЛИЧНОСТИ ПРОФЕССИОНАЛА ИНЖЕНЕРА-ПЕДАГОГА}

Аннотация: Развитие личности определяет выбор профессии и подготовку к ней. Сам выбор и развитие профессиональной деятельности определяют стратегию развития личности. Профессиональное развитие на разных этапах жизнедеятельности человека является то результатом, то средством развития личности.

Чем раньше начнется направленное личностное и профессиональное развитие, тем в большей степени можно прогнозировать психологическое благополучие, удовлетворенность жизнью и личностный рост каждого человека в современном, меняющемся мире.

Ключевые слова: личность, развитие, самосознание, рост.

Специфика психологических проблем современности определяется необходимостью освоения нового социально - экономического и профессионального опыта.

В XX веке одно из лучших объяснений социальной сущности личности было осуществлено в рамках культурно-исторической теории Л. С. Выготского [5,c.8], согласно которой личность не "созревает" из внутренних предпосылок, а "формируется", достраивается на биологическом фундаменте той системой общественных отношений, в которых развивается человек. Высшие психические функции не представлены в человеке от рождения, а даны лишь в виде потенциальной возможности. Переход из потенциального в актуальное происходит благодаря взаимодействию природных и социальных факторов в процессе социализации.

Все индивидуальные проявления личности человека невозможно объяснить влиянием системы общественных отношений или вывести их из индивидных характеристик. Понятий "индивид" и "личность" недостаточно для описания высших способностей человека и ярких проявлений его творческой активности. Это ограничение можно преодолеть, используя понятие "индивидуальность". Б.Г.Ананьев рассматривает "индивидуальность" как надличностное образование, высшее 
проявление человека, интегративно объединяющее понятия "индивид", "личность" и "субъект деятельности".

Если личность - это социальная сущность человека, значит, она несет на себе отпечаток общественной системы и является ее продуктом. Для личности одной из существенных потребностей является потребность выполнения общественного долга.

Смещение требований к инженеру-педагогу в сторону его результативности делает приоритетной модель педагогического стиля преподавателя, ориентированного, прежде всего на содержание учебного предмета, на соответствие принятым стандартам подготовленности студентов для получения престижной работы, обеспечивающей желаемый образ жизни. Но вузы должны не только выполнять социальный заказ общества: готовить специалистов. Образование призвано опережать другие сферы общественной жизни человека и быть фактором развития общества.

Одна из главных целей высшей школы состоит в развитии у студентов заинтересованности и потребности в самоизменении. Превращение студента в субъекта, заинтересованного в самоизменении, обусловливает в дальнейшем его становление как профессионала, способного к построению своей деятельности, ее изменению и развитию.

Самореализация личности всегда характеризуется ситуацией, когда личность становится субъектом собственного развития. Это хорошо подтверждается мнением Ф. Баррона [3,c.153], считающего способность проектировать себя главной функцией личности, осуществляемой посредством творчества.

Рассматривая сложную диалектику влияния наследственности, среды и воспитания на развитие личности, когда приобретенные качества становятся новыми внутренними условиями развития, украинский психолог Г. С. Костюк пришел к идее саморазвития: "Возникают высшие формы самодвижения развивающейся личности, выражающиеся в ее сознательной целеустремленности, в стремлении работать над собой, вырабатывать у себя те или иные качества, руководствуясь определенным идеалом, подчинять своей власти игру сил своей собственной природы. При наличии такой целеустремленности личность до некоторой степени сама начинает руководить своим собственным психическим развитием". Профессиональное развитие неотделимо от личностного развития. В основе лежит принцип саморазвития, детерминирующий способность личности превращать собственную жизнедеятельность в предмет практического преобразования, приводящий к высшей форме жизнедеятельности личности - творческой самореализации. Основные научные подходы к изучению человека, могут быть объединены в рамках личностно - развивающего подхода, позволяющего понять объект и условия, механизм, движущие силы и динамику профессионального развития личности.

В личностно-развивающем подходе выделяются три основных направления профессионального развития личности: содержательное, динамическое и институциональное.

Развитие предполагает формирование новых потребностей. Помимо активности, вытекающей из базовых потребностей, и направленной на адаптацию в конкретной ситуации, существует надситуативная, или неадаптивная активность личности. Она не может быть объяснена с позиций теории адаптации, но хорошо вписывается в концепции самореализации личности.

Фактором личностного и профессионального развития человека являются внутренняя среда личности, ее активность, потребность в самореализации. Объектом профессионального развития и формой реализации творческого потенциала человека в профессиональном труде являются такие характеристики его личности как: направленность, компетентность и эмоциональная и поведенческая гибкость. Выделенные характеристики личности профессионала являются психологической 
основой, необходимой во всех видах деятельности. Каждая характеристика представляет собой определенное сочетание значимых личностных качеств, существенных для успешного действования в рамках конкретной профессии. Фундаментальным условием развития характеристик личности профессионала являются осознание им необходимости изменения, преобразования своего внутреннего мира и поиск новых возможностей самосуществования в труде, повышение уровня профессионального самосознания.

По С.Л. Рубинштейну, проблема самосознания есть, прежде всего, проблема определения своего способа жизни. Такой способ выводит человека за пределы существования и связан с появлением ценностно-смыслового определения жизни.

В своем профессиональном развитии человек характеризуется способностью выйти за пределы непрерывного потока повседневной практики, увидеть свой труд в целом и превратить его в предмет практического преобразования. Эта способность дает ему возможность стать хозяином положения, конструирующим свое настоящее и будущее.

Осознание инженером-педагогом своих потенциальных возможностей, перспективы личностного и профессионального роста побуждает его к постоянному эксперементированию, которое понимается как поиск, творчество, возможность выбора. Решающим элементом такой ситуации профессионального развития является необходимость делать выбор: ощущать свободу, с одной стороны, и ответственность за все, что происходит и произойдет, - с другой.

Потребности профессионального роста может сформировать лишь особая личностная направленность, точнее состояние, которое мы называем готовностью к самореализации. Эти потребности удовлетворяются разными формами активности, среди которых одно из ведущих мест занимает творческая деятельность. Одним из мотивов творчества выступает желание самореализоваться.

Источником саморазвития выступают потребности в самореализации, являющиеся продуктом развития личности.

Рассматривая профессиональное развитие как непрерывный процесс самопроектирования личности, можно выделить три основные стадии психологической перестройки личности: самоопределение, самовыражение и самореализацию. На стадии самореализации соотнесение знаний о себе происходит в рамках « Я и творческое Я». На этой стадии формируется жизненная философия человека в целом, осознается смысл жизни, своя общественная ценность. Человек достигает профессионального мастерства, гармонично развивает свою личность, творчески самореализуется.

Профессиональное развитие личности это выбор оптимального поведенческого решения.

Цепочка самореализации многовариантна. Решающую роль играет личный, часто сознательный выбор субъекта. Именно этот выбор и лежит в основе творения себя, самореализации. Лишь на высшем уровне человек становится субъектом развития себя. На предыдущих уровнях его формирование обусловлено внешними влияниями.

Психологическая готовность к самореализации - это системное явление, проявляющееся в виде ситуативной или долговременной, устойчивой готовности, являющееся диалектическим единством психических состояний и свойств личности.

Самореализацией, саморазвитием мы называем развитие личности, предполагающие высокую активность субъекта. Даже в недостаточно благоприятных социальных условиях активность выступает средством самореализации.

Развитие способностей возможно только при определенном уровне социализации человека, без которой не формируется готовность к самореализации.

Можно высказать идею о существовании готовности к самореализации на уровне общественного сознания. Если использовать понятие "коллективного субъекта", 
то в данном случае нужно рассматривать понятие "коллективного субъекта жизнетворчества". Это особая общественная атмосфера, высокий уровень интеллектуально-нравственного потенциала социальной общности, способствующий расцвету и самораскрытию талантов.

Общественно-психологическая готовность к самореализации это,"коллективная индивидуальность", она создается интеграцией индивидуальностей. Психологическим фундаментом личности будущего профессионала в любой области человеческой деятельности выступают такие базовые характеристики, как личностная направленность, поведенческая гибкость и профессиональная компетентность. Это все позволит будущему профессионалу инженеру-педагогу реализовать особенные ценностные эталоны. Это ценностные эталоны, которыми руководствуются общества развитых стран Запада и Востока; они основаны, прежде всего, на признании важности и уникальности отдельной личности. Специфической чертой является то, что отношения ориентируются на вполне конкретные и актуальные ожидания, связанные по преимуществу с потребностями людей в самоуважении и в достижении общности с другими.

Таким образом, инженеры-педагоги должны развивать у студентов необходимые характеристики личности, создать возможность продуктивного решения задач своего возраста, психологически грамотно ввести их в смысл, назначение, ценности, содержание профессиональной деятельности, а значит обеспечить условия профессионального развития личности на всех этапах жизненного пути.

Развитие личности определяет выбор профессии и подготовку к ней. Сам выбор и развитие профессиональной деятельности определяют стратегию развития личности. Профессиональное развитие на разных этапах жизнедеятельности человека является то результатом, то средством развития личности.

Чем раньше начнется направленное личностное и профессиональное развитие, тем в большей степени можно прогнозировать психологическое благополучие, удовлетворенность жизнью и личностный рост каждого человека в современном, меняющемся мире.

\section{References:}

1. Абульханова К. А. Соотношение индивидуальности и личности в свете субъектного подхода // Мир психологии. Научно-методический журнал. 2011. № 1. С. 22-31.

2. Асмолов А. Психология личности. М., «Смысл», 2005- 415 с.

3. Баррон Ф. Личность как функция проектирования человеком самого себя // Вопросы психологии. - 1990. - № 2. - С. 153-159.

4. Брушлинский А. В. Проблемы психологии субъекта. - М.: ИП РАН, 2006. - 109 с.

5. Выготский Л. С. История развития высших психических функций // Собр. соч. - К.: Педагогика, 2007. - Т. 8. - С. 6-328.

6. Горностай П. П. Личность и роль: Ролевой подход в социальной психологии личности. - К.: "Интерпресс ЛТД", 2007. - 312 с.

7. Гофман И. Представление себя другим в повседневной жизни / Пер. с англ. - М.: "Канон-пресс-Ц", "Кучково поле", 2000. - 304 с.

8. Костюк Г. С. - корифей української психологічної школи // Психолог. - 2008. - №3. - C. 12-13.

9. Маслоу А. Г. Дальние пределы человеческой психики / Пер. с англ. - СПб.: Изд. гр. "Евразия",2005. - 430 с.

10. Морено Я. Психодрама / Пер. с англ. - М.: Апрель Пресс, ЭКСМО-Пресс, 2004. $528 \mathrm{c}$.

11. Петровский В. А. Индивидуальность и саморегуляция: опыт мультисубъектной теории.Мир психологии. Научно-методический журнал. 2007. № 1 (49). С. 13-31. 